\title{
Correction to: Implications of Individual QT/RR Profiles—Part 2: Zero QTc/RR Correlations Do Not Prove QTc Correction Accuracy in Studies of QTc Changes
}

\author{
Marek Malik $^{1}\left(\right.$ ) $\cdot$ Christine Garnett $^{2} \cdot$ Katerina Hnatkova $^{1} \cdot$ Jose Vicente $^{2} \cdot$ Lars Johannesen $^{3} \cdot$ Norman Stockbridge $^{2}$
}

Published online: 6 February 2019

(c) The Author(s) 2019

\section{Correction to: Drug Safety}

https://doi.org/10.1007/s40264-018-0735-2

The Open Access license, which previously read:

Open Access This article is distributed under the terms of the Creative Commons Attribution-NonCommercial 4.0 International License (http://creativecommons.org/licenses/ by-nc/4.0/), which permits any noncommercial use, distribution, and reproduction in any medium, provided you give appropriate credit to the original author(s) and the source, provide a link to the Creative Commons license, and indicate if changes were made.
The original article can be found online at https://doi.org/10.1007/ s40264-018-0735-2.

Marek Malik

marek.malik@btinternet.com

1 National Heart and Lung Institute, Imperial College, Dovehouse Street, London SW3 6LY, England, UK

2 Division of Cardiovascular and Renal Products, Office of New Drugs, Center for Drug Evaluation and Research, US Food and Drug Administration, Silver Spring, MD, USA

3 Division of Clinical Pharmacology I, Office of Clinical Pharmacology, Center for Drug Evaluation and Research, US Food and Drug Administration, Silver Spring, MD, USA
Should read:

Open Access This article is distributed under the terms of the Creative Commons Attribution 4.0 International License (http://creativecommons.org/licenses/by/4.0/), which permits unrestricted use, distribution, and reproduction in any medium, provided you give appropriate credit to the original author(s) and the source, provide a link to the Creative Commons license, and indicate if changes were made.

Open Access This article is distributed under the terms of the Creative Commons Attribution 4.0 International License (http://creativeco mmons.org/licenses/by/4.0/), which permits unrestricted use, distribution, and reproduction in any medium, provided you give appropriate credit to the original author(s) and the source, provide a link to the Creative Commons license, and indicate if changes were made. 